\title{
Maternal near-miss in labor and delivery in the light of technologies in health*
}

\author{
Near miss materno no trabalho de parto e parto à luz das tecnologias em saúde \\ Near miss materno en el trabajo de parto y parto a la luz de las tecnologías sanitarias
}

Izabel Dayana de Lemos Santos ${ }^{1}$, Fabiana Fontana Medeiros ${ }^{1}$, Rosângela Aparecida Pimenta Ferrari ${ }^{2}$, Deise Serafim², Sandra Mara Maciel ${ }^{3}$, Alexandrina Aparecida Maciel Cardelli²

How to cite this article:

Santos IDL, Medeiros FF, Ferrari RAP, Serafim D, Maciel SM, Cardelli AAM. Maternal near-miss in labor and delivery in the light of technologies in health. Rev Esc Enferm USP. 2018;52:e03409. DOI: http://dx.doi.org/10.1590/S1980-220X2017049603409

* Extracted from the dissrtation: "Near miss materno: entre mulheres no período de trabalho de parto e parto", Universidade Estadual de Londrina, 2017.

${ }_{1}^{1}$ Universidade Estadual de Londrina, Programa de Pós-Graduação em Enfermagem, Londrina, PR, Brazil.

${ }^{2}$ Universidade Estadual de Londrina, Centro de Ciências da Saúde, Departamento de Enfermagem, Londrina, PR, Brazil.

${ }^{3}$ Universidade Estadual de Maringá, Maringá, PR, Brazil.

\begin{abstract}
Objective: To know maternal near-miss situations during labor and delivery according to technologies in health. Method: A quantitative study conducted with puerperal women in a public institution in which the maternity department is a reference for high risk care. Data collection was performed from October 2016 to August 2017, and data were processed in SPSS 20.0. Technologies in health were used for discussing the results. Results: Participation of 319 puerperal women. Primiparous women $(p=0.027)$, previous diagnosis of hypertension $(\mathrm{p}=0.0001)$, preeclampsia $(\mathrm{p}=0.0001)$ and urinary tract infection $(p=0.002)$ were items with statistical significance for the maternal near-miss outcome in labor and delivery. The hard technology associated with the outcome was transportation for hospitalization $(p=0.035)$. Among the light-hard technologies, the following were associated: characteristics of amniotic fluid $(\mathrm{p}=0.05)$, vital signs check $(\mathrm{p}=0.0001)$, and initiation of the partograph for cesarean section ( $\mathrm{p}=0.026$ ). Among the light technologies, user satisfaction was relevant $(\mathrm{p}=0.007)$. Conclusion: Health technologies can be used for structuring the assistance in order to prevent maternal near-miss.
\end{abstract}

\section{DESCRIPTORS}

Near Miss, Healthcare; Pregnancy, High-Risk; Parturition; Obstetric Nursing; Technology. 


\section{INTRODUCTION}

The theme of patient safety deserves attention from health professionals at all levels of care, which includes women's care at the time of labor and delivery in order to reduce maternal morbidity and mortality in this process ${ }^{(1)}$.

In 2000, the United Nations (UN) held a conference to establish proposals for the Millennium Development Goals, which should be achieved by 2015 , including a significant reduction in maternal mortality ${ }^{(2)}$.

A new UN meeting was held in 2015, when goals for sustainable development were set. The third of these objectives was "to ensure a healthy life and promote wellbeing for all". One of its goals included reducing maternal mortality with the proposal not to exceed the rate of 70 women per 100,000 live births by $2030^{(3)}$.

Based on the above, in Brazil, many protocols that qualified women's care focused on managing aggravation and providing guidelines for the increase of women's safety in the pregnancy-puerperal cycle were implemented. The current maternal mortality rate in Brazil is 26 women per 100,000 live births, which is well below that proposed in the sustainable development goals ${ }^{(4)}$.

Therefore, the need for continuous investment in protocols and evidence-based updates in order to further reduce this rate, since even with tools for the safe outcome of pregnancy, there are still women experiencing severe morbidity events or maternal near-miss (MNM) $)^{(5-6)}$.

In 2011, the World Health Organization (WHO) defined MNM as the situation in which women experience severe, life-threatening morbidities, and established criteria to identify them in order that necessary interventions are performed, thereby ensuring these women's wellbeing. The near-miss can occur during pregnancy, labor, delivery and puerperal period, and up to 42 days postpartum ${ }^{(7)}$.

Women's care based on health technologies is one of the proposed points for achieving safer care. In this sense, by considering the triad of hard, light-hard and light technologies in health, it is interesting that the management of near-miss is intrinsically linked to the flexibility of using such tools ${ }^{(8)}$.

In the present study, the aim is to know maternal nearmiss situations during labor and delivery assistance according to technologies in health.

\section{METHOD}

\section{TYPE OF STUDY}

This is a quantitative, cross-sectional and analytical study that is a prospective cohort on high-risk pregnancy. It was developed in the maternity of a public institution that provides assistance to obstetric intercurrences and high complexity deliveries. Service is provided exclusively by the Brazilian Unified Health System (Portuguese acronym: SUS) in a municipality in the southern region of the country.

\section{DATA COLLECTION}

Women diagnosed with high-risk pregnancy according to the Ministry of Health protocol ${ }^{(6)}$, with at least one
MNM criterion according to $\mathrm{WHO}^{(7)}$ and able to understand and give their consent for participation in the study were included. The objective of the study was clarified to all participants and they were asked to sign the Informed Consent (IC) form. The sample calculation was based on the annual report of deliveries at the institution of the year prior to the study. The following were considered: sample error of 5\%, confidence level of $95 \%$, and a universe of 1,045 births on year 2015. The sample consisted of 319 women $^{(9)}$.

A pilot study was conducted for adjustment of the instrument. Data collection was performed subsequently in the period from October 2016 to August 2017. Data were obtained by means of transcription of the medical chart, prenatal card, interview with all puerperal women, and description of the institutional structure of care. In order to guarantee the complete coverage of data, at the end of each case, the form was checked, as well as the medical charts and prenatal cards, and the re-interview by telephone in situations of hospital discharge was performed.

The form was structured to provide access to socioeconomic, demographic and obstetric data according to the health technologies proposed by Merhy ${ }^{(10)}$, in which they are presented as facilitators for the diagnosis of the healthcare process. Technologies are the following: hard technology (HT) is directly linked to the material and physical structure of the institution; light-hard technology (LHT) refers to the scientific knowledge that bases the care performed, and is obtained through indicators of care at admission, obstetric practices in labor, delivery management and near-miss criteria; and the light technology (LT) is directed to the interpersonal relationship established between health professionals and users through dialogue and empathy, and is obtained through the indicator of users' level of satisfaction.

\section{ANALYSIS AND PROCESSING OF DATA}

Data were processed in the Statistical Package for the Social Sciences (SPSS) software, version 20.0, and analyzed by means of the chi-square test for searching possible associations $(p \leq 0.05)$. The following dependent variables were used: 'maternal near-miss outcome in labor and delivery (MNMOLD)' and 'user satisfaction in relation to care' (obtained through women's reports of their expectations met in relation to guidelines and the interpersonal relationship with the health team).

\section{ETHICAL ASPECTS}

In compliance with determinations of Resolution 466/12 of the National Health Council, the study was approved by the Research Ethics Committee in Research Involving Human Beings of the Universidade Estadual de Londrina (CEP/UEL) under number 1.757.596.

\section{RESULTS}

This study included 319 women, most of whom (70.5\%) were between 20 and 35 years of age, $18.5 \%$ were aged 36 years or over, and $11 \%$ were adolescents. The race was predominantly white $(57.8 \%)$, the majority $(86.8 \%)$ had 
a partner, a little more than half (56.0\%) had completed secondary education, $48.6 \%$ of families received more than three minimum wages. In the obstetric profile, there was statistical significance between the number of children and the maternal near-miss outcome in labor and delivery (MNMOLD) ( $\mathrm{p}=0.027)$. Primiparous women had a higher incidence of MNMOLD (40.5\%) (Table 1).

The analysis of the moment of MNM occurrence in the studied population demonstrated that $55.6 \%$ went through this situation during pregnancy, $19.5 \%$ during labor and delivery, and $25.4 \%$ from pregnancy until delivery.

Table 2 shows a statistically significant association between previous hypertension $(\mathrm{p}=0.0001)$, preeclampsia $(\mathrm{p}=0.0001)$, urinary tract infection ( $\mathrm{p}=0.002)$, and MNMOLD.

According to the hard and light-hard technologies with regard to structure, the institution has the following: a predelivery room with two beds; two wards with shared rooms with nine beds; an inpatient ward with six beds for the hospitalization of pregnant women at risk; a delivery room with a gynecological table and a specific place inside the delivery room for the first care to the newborn; another setting for daily care of newborns in shared accommodation, and one for nursing care; two shared bathrooms for all hospitalized women. The service also has the necessary supplies and materials for assistance to women at high-risk.

Regarding assistance during admission for labor, there was a significant statistical difference between the transport for hospitalization $(p=0.035)$, vital signs check $(p=0.0001)$ and the characteristics of amniotic fluid $(p=0.05)$ and MNMOLD. Among women who sought hospitalization, $57.6 \%$ used private transportation, $55.2 \%$ of women did not have their vital signs checked, and $69.0 \%$ had no records of the amniotic fluid characteristic (Table 3).

In obstetric practices during labor, the initiation of partograph for cesarean section $(54.3 \%)$ was associated with MNMOLD ( $p=0.026)$. There was no association between labor management and MNMOLD. However, 32.9\% of women were hospitalized with dilation of less than $4 \mathrm{~cm}$, $34.2 \%$ without effective uterine dynamics, $65.8 \%$ had no induction of labor, and in $60.2 \%$ the outcome of pregnancy was the cesarean section. As for obstetric routines, there was no orientation for bathing for relaxation (86.5\%), use of active ball or birthing chair $(90.8 \%)$, companion at delivery (58.2\%) and massage for pain relief (98.1\%) (Table 3).

Table 1 - Distribution of women according to socioeconomic, demographic, obstetric characterization, and maternal near-miss outcome in labor and delivery - Londrina, PR, Brazil, 2017.

\begin{tabular}{|c|c|c|c|c|c|c|c|}
\hline \multirow{3}{*}{ Variables } & \multicolumn{6}{|c|}{ Maternal near-miss outcome in labor and delivery } & \multirow{3}{*}{ P value } \\
\hline & \multicolumn{2}{|c|}{ Yes } & \multicolumn{2}{|c|}{ No } & \multicolumn{2}{|c|}{ Total } & \\
\hline & $\mathbf{n}$ & $\%$ & $\mathbf{n}$ & $\%$ & $\mathbf{n}$ & $\%$ & \\
\hline \multicolumn{8}{|l|}{ Age range (years) } \\
\hline $14-19$ & 23 & 11.0 & 12 & 11.0 & 35 & 11.0 & 0.693 \\
\hline $20-35$ & 150 & 71.4 & 75 & 68.8 & 225 & 70.5 & \\
\hline 36 and older & 37 & 17.6 & 22 & 20.2 & 59 & 18.5 & \\
\hline \multicolumn{8}{|l|}{ Maternal race } \\
\hline White & 11 & 56.6 & 65 & 60.2 & 181 & 57.8 & 0.550 \\
\hline Black & 89 & 43.4 & 43 & 39.8 & 132 & 42.2 & \\
\hline \multicolumn{8}{|l|}{ Marital status } \\
\hline With partner & 17 & 85.2 & 98 & 89.9 & 277 & 86.8 & 0.296 \\
\hline No partner & 31 & 14.8 & 11 & 10.1 & 42 & 13.2 & \\
\hline \multicolumn{8}{|l|}{ Education al level } \\
\hline Primary school & 61 & 29.2 & 30 & 27.5 & 91 & 28.6 & 0.538 \\
\hline Secondary school & 11 & 56.6 & 60 & 55.0 & 178 & 56.0 & \\
\hline Higher education & 30 & 14.4 & 19 & 17.4 & 49 & 15.4 & \\
\hline \multicolumn{8}{|c|}{ Family income $(\mathrm{MW})^{* *}$} \\
\hline$\leq 1$ & 30 & 14.3 & 19 & 17.4 & 49 & 15.4 & \\
\hline 1 to 2 & 75 & 35.7 & 40 & 36.7 & 115 & 36.1 & 0.648 \\
\hline$\geq 3$ & 105 & 50.0 & 50 & 45.0 & 155 & 48.6 & \\
\hline \multicolumn{8}{|l|}{ Number of children } \\
\hline Primiparous & 85 & 40.5 & 37 & 33.9 & 122 & 38.2 & 0.027 \\
\hline Secundiparous & 75 & 35.7 & 30 & 27.5 & 105 & 32.9 & \\
\hline Multiparous & 50 & 23.8 & 42 & 38.5 & 92 & 28.8 & \\
\hline \multicolumn{8}{|c|}{ Interval between births } \\
\hline$<2$ years & 24 & 61.5 & 15 & 38.5 & 39 & 18.8 & 0.395 \\
\hline$\geq 2$ years & 116 & 68.6 & 53 & 31.4 & 169 & 81.2 & \\
\hline
\end{tabular}

${ }^{*}$ Chi-square test $(\mathrm{p}<0.05) ;{ }^{* *}$ Minimum wage in 2017: R\$937.00. 
Table 2 - Distribution of women according to presence of near-miss criteria prior to hospitalization for delivery and maternal nearmiss outcome from pregnancy until delivery - Londrina, PR, Brazil, 2017.

\begin{tabular}{|c|c|c|c|c|c|c|c|}
\hline \multirow{3}{*}{$\begin{array}{l}\text { Presence of near-miss criteria prior to } \\
\text { hospitalization for delivery }\end{array}$} & \multicolumn{6}{|c|}{ Maternal near-miss outcome in labor and delivery } & \multirow{3}{*}{ P value* } \\
\hline & \multicolumn{2}{|c|}{ Yes } & \multicolumn{2}{|c|}{ No } & \multicolumn{2}{|c|}{ Total } & \\
\hline & $\mathbf{n}$ & $\%$ & n & $\%$ & $\mathbf{n}$ & $\%$ & \\
\hline \multicolumn{8}{|l|}{ Hypertension } \\
\hline Yes & 117 & 92.1 & 10 & 7.9 & 127 & 39.8 & 0.0001 \\
\hline No & 93 & 48.4 & 99 & 51.6 & 192 & 60.2 & \\
\hline \multicolumn{8}{|l|}{ Heart disease } \\
\hline Yes & 8 & 57.1 & 6 & 42.9 & 14 & 4.4 & 0.567 \\
\hline No & 202 & 66.2 & 103 & 33.8 & 305 & 95.6 & \\
\hline \multicolumn{8}{|l|}{ Preeclampsia } \\
\hline Yes & 48 & 92.3 & 4 & 7.7 & 52 & 16.3 & 0.0001 \\
\hline No & 162 & 60.7 & 105 & 39.3 & 267 & 83.7 & \\
\hline \multicolumn{8}{|l|}{ Urinary tract infection } \\
\hline Yes & 16 & 43.2 & 21 & 56.8 & 37 & 11.6 & 0.002 \\
\hline No & 194 & 68.8 & 88 & 31.2 & 282 & 88.4 & \\
\hline \multicolumn{8}{|l|}{ Mental disorder } \\
\hline Yes & 11 & 64.7 & 6 & 35.3 & 17 & 5.3 & 0.920 \\
\hline No & 199 & 65.9 & 103 & 34.1 & 302 & 94.7 & \\
\hline \multicolumn{8}{|l|}{ Coagulation disorder } \\
\hline Yes & 15 & 75.0 & 5 & 25.0 & 20 & 6.3 & 0.373 \\
\hline No & 195 & 65.2 & 104 & 34.8 & 299 & 93.7 & \\
\hline
\end{tabular}

*Chi-square test $(\mathrm{p}<0.05)$.

Table 3 - Distribution of women according to hard and light-hard technologies offered during hospitalization care, obstetric practices in labor, delivery management, and near-miss outcome in labor and delivery - Londrina, PR, Brazil, 2017.

\begin{tabular}{|c|c|c|c|c|c|c|c|}
\hline \multirow{3}{*}{ Variables } & \multicolumn{6}{|c|}{ Maternal near-miss outcome in labor and delivery } & \multirow{3}{*}{ P value* } \\
\hline & \multicolumn{2}{|c|}{ Yes } & \multicolumn{2}{|c|}{ No } & \multicolumn{2}{|c|}{ Total } & \\
\hline & $\mathbf{n}$ & $\%$ & $\mathbf{n}$ & $\%$ & $\mathbf{n}$ & $\%$ & \\
\hline \multicolumn{8}{|c|}{ Transportation for hospitalization } \\
\hline Ambulance & 89 & 42.4 & 33 & 10.3 & 122 & 38.2 & 0.035 \\
\hline Private transportation & 121 & 57.6 & 76 & 69.7 & 197 & 61.8 & \\
\hline \multicolumn{8}{|c|}{ Checking of vital signs at admission } \\
\hline Yes & 94 & 44.8 & 20 & 18.3 & 114 & 35.7 & 0.0001 \\
\hline No & 116 & 55.2 & 89 & 81.6 & 205 & 64.2 & \\
\hline \multicolumn{8}{|l|}{ Dilation at admission } \\
\hline$<4 \mathrm{~cm}$ & 69 & 32.9 & 36 & 33.0 & 105 & 32.9 & 0.166 \\
\hline$\geq 4 \mathrm{~cm}$ & 49 & 23.3 & 37 & 33.9 & 86 & 26.9 & \\
\hline No record & 92 & 43.8 & 36 & 33.0 & 128 & 40.1 & \\
\hline \multicolumn{8}{|c|}{ Uterine dynamics at admission } \\
\hline Present & 89 & 42.4 & 53 & 48.6 & 142 & 44.5 & 0.561 \\
\hline Absent & 75 & 35.7 & 34 & 31.2 & 109 & 34.2 & \\
\hline No record & 46 & 21.9 & 22 & 20.2 & 68 & 21.3 & \\
\hline \multicolumn{8}{|c|}{ Characteristic of amniotic fluid } \\
\hline Clear & 61 & 29.0 & 31 & 28.4 & 92 & 28.8 & 0.050 \\
\hline Meconium & 4 & 1.9 & 8 & 7.3 & 12 & 3.8 & \\
\hline No record & 145 & 69.0 & 70 & 64.2 & 215 & 67.4 & \\
\hline \multicolumn{8}{|c|}{ Oxytocin induction of labor } \\
\hline Yes & 75 & 35.7 & 34 & 31.2 & 109 & 34.2 & 0.420 \\
\hline No & 135 & 64.3 & 75 & 68.8 & 210 & 65.8 & \\
\hline \multicolumn{8}{|l|}{ Relaxation bath in labor } \\
\hline Yes & 15 & 7.1 & 6 & 5.5 & 21 & 6.6 & 0.691 \\
\hline No & 13 & 6.2 & 9 & 8.3 & 22 & 6.9 & \\
\hline No record & 182 & 86.7 & 94 & 86.2 & 276 & 86.5 & \\
\hline \multicolumn{8}{|c|}{ Ball or birthing chair in labor } \\
\hline Yes & 4 & 2.0 & 4 & 4.1 & 8 & 2.7 & 0.390 \\
\hline No & 12 & 6.1 & 7 & 7.1 & 19 & 6.5 & \\
\hline No record & 180 & 91.8 & 87 & 29.6 & 267 & 90.8 & \\
\hline
\end{tabular}




\begin{tabular}{|c|c|c|c|c|c|c|c|}
\hline \multirow{3}{*}{ Variables } & \multicolumn{6}{|c|}{ Maternal near-miss outcome in labor and delivery } & \multirow{3}{*}{ P value* } \\
\hline & \multicolumn{2}{|c|}{ Yes } & \multicolumn{2}{|c|}{ No } & \multicolumn{2}{|c|}{ Total } & \\
\hline & $\mathbf{n}$ & $\%$ & $\mathbf{n}$ & $\%$ & $\mathbf{n}$ & $\%$ & \\
\hline \multicolumn{8}{|l|}{ Use of massage in labor } \\
\hline Yes & 3 & 1.4 & 3 & 2.8 & 6 & 1.9 & 0.449 \\
\hline No record & 207 & 98.6 & 106 & 97.2 & 313 & 98.1 & \\
\hline \multicolumn{8}{|l|}{ Pre-birth companion } \\
\hline Yes & 114 & 60.6 & 54 & 51.9 & 168 & 57.5 & 0.174 \\
\hline No & 74 & 39.4 & 50 & 48.1 & 124 & 42.5 & \\
\hline \multicolumn{8}{|l|}{ Partograph } \\
\hline Up to 3 hours & 32 & 15.2 & 28 & 25.7 & 60 & 18.8 & 0.026 \\
\hline More than 3 hours & 26 & 12.4 & 15 & 13.8 & 41 & 12.9 & \\
\hline No record & 38 & 18.1 & 20 & 18.3 & 58 & 18.2 & \\
\hline Initiation for cesarean section** & 114 & 54.3 & 46 & 42.2 & 160 & 50.2 & \\
\hline \multicolumn{8}{|l|}{ Companion during labor } \\
\hline Yes & 76 & 39.0 & 45 & 46.4 & 121 & 41.6 & 0.226 \\
\hline No & 119 & 61.0 & 52 & 53.6 & 171 & 58.6 & \\
\hline \multicolumn{8}{|l|}{ Place of delivery } \\
\hline Bedroom & 6 & 2.9 & 7 & 6.4 & 13 & 4.1 & 0.131 \\
\hline Delivery room & 68 & 32.4 & 38 & 34.9 & 106 & 33.2 & \\
\hline Surgical center & 136 & 64.8 & 64 & 58.7 & 200 & 62.7 & \\
\hline \multicolumn{8}{|l|}{ Type of birth } \\
\hline Natural & 81 & 38.6 & 46 & 14.4 & 127 & 39.8 & 0.530 \\
\hline Cesarean section & 129 & 61.4 & 63 & 57.8 & 192 & 60.2 & \\
\hline
\end{tabular}

${ }^{*}$ Chi-square test $(\mathrm{p}<0.05)$; ** Partograph initiated only to record the motive for cesarean section.

Among the light technologies, there was statistical significance in relation to receiving the desired orientations $(\mathrm{p}=0.013)$; information about the companion $(\mathrm{p}=0.022)$; kind treatment by the team $(\mathrm{p}=0.0001)$; information on clinical status $(\mathrm{p}=0.005)$; explanation of procedure performed $(p=0.007)$; good relationship with the team $(\mathrm{p}=0.005)$; freedom to clarify questions $(\mathrm{p}=0.007)$; presentation of the team $(\mathrm{p}=0.026)$ and satisfaction with care. It was found that $44.5 \%$ did not receive the guidelines they wanted; $38.9 \%$ were not informed about the right of having a companion, but $54.6 \%$ were treated with kindness; 86.9\% had information about their clinical condition; $85.9 \%$ received explanations about the procedures performed; 95.1\% reported a good relationship with the team; $96.1 \%$ felt free to clarify questions; and $94.3 \%$ stated that the team presented themselves (Table 4).

Table 4 - Distribution of women according to light technologies offered and satisfaction with the service - Londrina, PR, Brazil, 2017.

\begin{tabular}{|c|c|c|c|c|c|c|c|}
\hline \multirow{3}{*}{ Variables } & \multicolumn{6}{|c|}{ Satisfaction with service } & \multirow{3}{*}{ P value $^{*}$} \\
\hline & \multicolumn{2}{|c|}{ Yes } & \multicolumn{2}{|c|}{ No } & \multicolumn{2}{|c|}{ Total } & \\
\hline & $\mathbf{n}$ & $\%$ & $\mathbf{n}$ & $\%$ & $\mathbf{n}$ & $\%$ & \\
\hline \multicolumn{8}{|c|}{ Guidance before delivery } \\
\hline Yes & 177 & 62,5 & 21 & 58,3 & 198 & 62,1 & 0,624 \\
\hline No & 106 & 37,5 & 15 & 41,7 & 121 & 37,9 & \\
\hline \multicolumn{8}{|c|}{ Desired orientation received } \\
\hline Yes & 157 & 55,5 & 12 & 33,3 & 169 & 53,0 & 0,013 \\
\hline No & 126 & 44,5 & 24 & 66,7 & 150 & 47,0 & \\
\hline \multicolumn{8}{|c|}{ Information about companion } \\
\hline Hospitalization & 108 & 38,2 & 11 & 30,6 & 119 & 37,3 & 0,022 \\
\hline Pre-labor & 43 & 15,2 & 8 & 22,2 & 51 & 16,0 & \\
\hline Delivery & 9 & 3,2 & 2 & 5,6 & 11 & 3,4 & \\
\hline Puerperal period & 13 & 4,6 & 6 & 16,7 & 19 & 6,0 & \\
\hline Not informed & 110 & 38,9 & 9 & 25,0 & 119 & 37,3 & \\
\hline \multicolumn{8}{|c|}{ Kind treatment by the team } \\
\hline Yes & 270 & 84,6 & 28 & 77,8 & 298 & 93,4 & 0,0001 \\
\hline No & 12 & 4,2 & 8 & 93,4 & 20 & 6,3 & \\
\hline No opinion & 1 & 0,4 & 0 & 0,0 & 1 & 0,3 & \\
\hline \multicolumn{8}{|c|}{ Information on clinical picture } \\
\hline Yes & 246 & 86,9 & 24 & 66,7 & 270 & 84,6 & 0,005 \\
\hline No & 37 & 13,1 & 12 & 33,3 & 49 & 15,4 & \\
\hline
\end{tabular}




\begin{tabular}{|c|c|c|c|c|c|c|c|}
\hline \multirow{3}{*}{ Variables } & \multicolumn{6}{|c|}{ Satisfaction with service } & \multirow{3}{*}{ P value* } \\
\hline & \multicolumn{2}{|c|}{ Yes } & \multicolumn{2}{|c|}{ No } & \multicolumn{2}{|c|}{ Total } & \\
\hline & $\mathbf{n}$ & $\%$ & $\mathbf{n}$ & $\%$ & $\mathbf{n}$ & $\%$ & \\
\hline \multicolumn{8}{|c|}{ Explanation of procedure performed } \\
\hline Yes & 243 & 85,9 & 24 & 66,7 & 267 & 83,7 & 0,007 \\
\hline No & 40 & 14,1 & 12 & 33,3 & 52 & 16,3 & \\
\hline Yes & 269 & 95,1 & 29 & 80,6 & 298 & 93,4 & 0,005 \\
\hline No & 14 & 4,9 & 7 & 19,4 & 21 & 6,6 & \\
\hline \multicolumn{8}{|c|}{ Freedom to clarify doubts } \\
\hline Yes & 272 & 96,1 & 30 & 83,3 & 302 & 94,7 & 0,007 \\
\hline No & 11 & 3,9 & 6 & 16,7 & 17 & 5,3 & \\
\hline \multicolumn{8}{|c|}{ Introduction of the team } \\
\hline No & 16 & 5,7 & 6 & 16,7 & 22 & 6,9 & \\
\hline
\end{tabular}

*Chi-square test $(\mathrm{p}<0.05)$.

\section{DISCUSSION}

Women at extremes of age, that is, adolescents and those over 35 years of age, are classified as intermediate risk in care protocols for pregnant women ${ }^{(5)}$. For a long time, pregnancy in adolescence was understood as a risk factor for young women's health and characterized as a public health problem. However, this paradigm is being broken currently, because this group's exposure to social risk is known to be much greater than exposure to biological risk ${ }^{(11)}$. The escape from the reality in which they live, and the fact that the social representation of being a mother gives them a specific and respected identity before society, are social determinants for maintaining the incidence of pregnancy in this age group $^{(12)}$. This reality was confirmed in this study, because there was no significant number of MNMOLD occurrence among adolescents.

Considering that women currently take longer to decide for a first pregnancy because of their daily lives, or even because of the search for social and financial stability, many of them have become pregnant after 35 years of age ${ }^{(13)}$. In the present study, the number of women who had MNMOLD after that age was not significant. Most studied women who had MNMOLD events were young adults of childbearing age.

In relation to the pregnancy-puerperal cycle, the predisposition to some specific condition may be related to primiparous women ${ }^{(14)}$. In this study, the proportion of MNMOLD in primiparous women was significant, similar to a study conducted in the state of Pernambuco in a reference maternity for high risk, in which $93.2 \%$ of primiparous women were at gestational risk ${ }^{(15)}$.

Although this study was focused on labor and delivery, the occurrence of near-miss during pregnancy reinforces the importance of quality prenatal care, accurate followup, and early identification of any type of change or presence of morbidity for intervention in a timely manner. The morbidities identified in this study were not different from those identified as determinants of high rates of national maternal mortality.

The epidemiological profile of these deaths constructed by the Health Surveillance Secretariat presents hypertension as the leading cause of maternal mortality with $20 \%$ of cases, and puerperal infections with $7 \%$, the third cause of maternal death in Brazil ${ }^{(16)}$.

In the design and implementation of LHT, the necessary subsidies for programming effective actions for the prevention of near-miss can be found, since they propose the knowledge of professionals as an essential factor for quality care. In this sense, the findings of the present study question to what extent the inadequate use of specific knowledge about the mentioned diseases, or the lack of care due to lack of such knowledge could be determining the occurrence of MNM.

In pregnancy, there are several presentations of hypertension known, namely: previously hypertensive pregnant women; pregnant women who develop hypertension after 20 weeks, and may evolve to preeclampsia, eclampsia or HELLP syndrome (hemolysis, elevated liver enzymes, low platelet count), which increases the likelihood of MNMOLD ${ }^{(17-18)}$. Urinary tract infection is another pathology present in the periods of pregnancy and giving birth of innumerable women, and which can progress to chorioamnionitis, puerperal infection or even sepsis. Again, the importance of the professional having skills that correspond to the light and hard technologies in health is emphasized in order to manage the presented pictures properly ${ }^{(19)}$.

In the same way that pre-delivery care is important, the moment of hospitalization is also significant, since from anamnesis and its record the best conduct will be chosen and demonstrated the LHT during assistance ${ }^{(5)}$. However, this moment is not always registered in the medical record. In the present study, lack of information on vital signs and characteristics of the amniotic fluid was identified. Vital signs provide important information about the initial state of women at high-risk ${ }^{(20)}$. The analysis of the amniotic fluid offers information on fetal status, as well as indications of risk for infection in parturient women that may extend to the puerperal period. Therefore, this information provides an adequate management of MNM cases ${ }^{(21)}$.

In this study, $32.9 \%$ of hospitalized women showed no signs of labor, which are dilation greater than four 
centimeters and presence of uterine dynamics, a conduct considered appropriate since these are women at high obstetric risk ${ }^{(22)}$. Most women in this study had a cesarean section as a resolution of gestation. Even though these are high rates, the indications were considered pertinent given the high-risk diagnosis involved, and demonstrated the adequate use of LHTs. Since 1996, the WHO has recommended that institutions have a maximum of $15 \%$ cesarean deliveries among the total deliveries ${ }^{(23)}$. However, a current publication recommended that institutions adopt the Robson's classification or classification of the 10 groups, which proposes groups with specific obstetric characteristics. Thus, each institution has its cesarean section rate according to the characteristics of women attended, which affirms the effectiveness in indicating the surgery ${ }^{(24)}$.

Humanized care is a proposal of the Ministry of Health for the assistance offered by the SUS and directly associated to light technologies, and women in situations of MNM should not be excluded from this service. In addition to professionals' awareness, one of the ways to humanize the moment of childbirth depends on the structure of the institution, which must offer: access to hot water, Swiss ball, complementary therapies for pain relief, and good interpersonal interaction of the team with the woman by involving the maintenance of a calm, comfortable and private environment, which shows the joint use of the triad of technologies in health ${ }^{(22-25)}$. Again, in this study, obstetric routines were not properly registered in medical records.

In relation to HT (hard technologies), the structure of the institution under analysis provides the means to perform examinations, ensure access to the intensive care unit if necessary, and also access to the operating room and the neonatal intensive care unit. Professionals have access to all necessary materials and supplies, which is extremely important for the care of MNM cases. However, the structure where the maternity is located has limitations, for example: toilets that are often used by extended periods of time during labor are insufficient; warm water is a non-pharmacological help for pain relief, but access to the shower is restricted ${ }^{(26)}$; and wide and airy corridors for walks of parturient women are not available, even though walking favors the progression of labor ${ }^{(27)}$.

Women's mean of transportation to the institution is also considered a HT. In this study, most women sought hospitalization by their own means, that is, private vehicles, and these women were the highest cases of MNMOLD. Parturient women are entitled the right of safe transportation through the Mobile Emergency Care System (Portuguese acronym: SAMU) for the referral hospital. This means of transport can meet any type of demand presented by parturient women along the way, and ensure their physiological stability ${ }^{(28)}$.

Day-to-day practice and the automatism of the caring process can harm the interpersonal relationship between professionals and users and favor the non-establishment of light technologies in the work environment. In this study, despite the limited resolution of women's specific demands during their hospitalization, their satisfaction was evident. This can be explained by the fact that for users, it is often more important to be treated with humanity than to have their pathologies or demands resolved ${ }^{(29-30)}$.

\section{CONCLUSION}

In this study, the presence of arterial hypertension, preeclampsia and urinary tract infection prior to admission to labor have determined the occurrence of maternal near-miss in labor and delivery due to hypertensive crisis, HELLP syndrome and puerperal infection, respectively. In this sense, it could be deduced that light-hard and hard technologies were not enough for the prevention of negative outcomes in the care offered to these women after hospitalization. However, these technologies were adequately implemented, and the determinants of near-miss cases in labor and delivery were the insufficient follow-up of maternal conditions during pregnancy and their hospitalization in a critical clinical picture. This diagnosis emphasizes the need for prenatal adjustment of women classified as high risk, which should include efficient clinical follow-up, use of light technologies for women's empowerment on their diagnosis and self-care, as well as effective conditions of access to the referral institution for the adequate delivery and minimization of risks.

The limitation of the study is the lack of information in medical records on women's care, which indicates the need for a review in the procedure of records of care, as this is an important health information system and essential for the analysis of the quality of care and, consequently, of patient safety.

Technologies in health can be a reference for structuring the care for high-risk labor and delivery, and have the aim of preventing maternal near-miss at these moments.

\section{RESUMO}

Objetivo: Conhecer situações de near miss materno durante a assistência ao trabalho de parto e parto, de acordo com as tecnologias em saúde. Método: Estudo quantitativo, realizado em uma instituição pública, cuja maternidade é referência para alto risco, com puérperas. A coleta de dados foi realizada no período de outubro de 2016 a agosto de 2017, e os dados foram processados no SPSS 20.0. Para a discussão dos resultados, foram utilizadas as tecnologias em saúde. Resultados: Participaram 319 puérperas. Primípara $(p=0,027)$, diagnóstico prévio de hipertensão $(p=0,0001)$, pré-eclâmpsia $(p=0,0001)$ e infecção do trato urinário $(p=0,002)$ foram itens que apresentaram significância estatística para o desfecho de near miss materno no trabalho de parto e parto. A tecnologia dura que se associou com o desfecho foi o transporte para internação $(p=0,035)$; entre as leve-duras, associaram-se as características do líquido amniótico $(p=0,05)$, verificação dos sinais vitais $(p=0,0001)$ e abertura do partograma para cesariana $(p=0,026)$; e entre as leves, a satisfação da usuária foi relevante $(p=0,007)$ Conclusão: Acredita-se que as tecnologias em saúde podem ser utilizadas para a estruturação da assistência para a prevenção do near miss materno.

Near Miss; Gravidez de Alto Risco; Parto; Enfermagem Obstétrica; Tecnologia. 
RESUMEN

Objetivo: Conocer situaciones de near miss materno durante la asistencia al trabajo de parto y parto, según las tecnologías sanitarias.

Método: Estudio cuantitativo, llevado a cabo en un centro público, cuya maternidad es referencia para alto riesgo, con puérperas. La recolección de datos se realizó en el período de octubre de 2016 a agosto de 2017, y los datos fueron procesados en el SPSS 20.0. Para la discusión de los resultados, fueron utilizadas las tecnologías sanitarias. Resultados: Participaron 319 puérperas. Primípara ( $p=0,027)$, diagnóstico previo de hipertensión $(p=0,0001)$, pre eclampsia $(p=0,0001)$ e infección del tracto urinario $(p=0,002)$ fueron puntos que presentaron significación estadística para el resultado de near miss materno en el trabajo de parto y parto. La tecnología dura que se asoció con el resultado fue el traslado a estancia hospitalaria $(p=0,035)$; entre las ligera-duras, se asociaron las características del líquido amniótico $(p=0,05)$, verificación de las señales vitales $(p=0,0001)$ y apertura del partograma para cesárea $(p=0,026)$; y, entre las ligeras, la satisfacción de la usuaria fue relevante $(p=0,007)$. Conclusión: Se cree que las tecnologías sanitarias pueden utilizarse para la estructuración de la asistencia a fin de prevenir el near miss materno.

\section{DESCRIPTORES}

Near Miss Salud; Embarazo de Alto Riesgo; Parto; Enfermería Obstétrica; Tecnología.

\section{REFERENCES}

1. Brasil. Ministério da Saúde; Agência Nacional de Vigilância Sanitária. Serviços de Atenção Materna e Neonatal: segurança e qualidade [Internet]. Brasília; 2014 [citado 2017 out. 20]. Disponível em: https://www20.anvisa.gov.br/segurancadopaciente/index.php/publicacoes/ item/servicos-de-atencao-materna-e-neonatal-seguranca-e-qualidade

2. United Nations Development Programme. Millennium Development Goals [Internet]. Nova York: UNDP; 2016 [cited 2017 Oct 15$].$ Available from: http://www.undp.org/content/undp/en/home/sdgoverview/mdg_goals.html

3. Organização das Nações Unidas, Centro Regional de Informações das Nações Unidas para a Europa Ocidental. Guia sobre desenvolvimento sustentável: 17 objetivos para transformar o nosso mundo [Internet]. Nova York; 2016 [citado 2017 out. 15]. Disponível em: https://www. unric.org/pt/images/stories/2016/ods_2edicao_web_pages.pdf

4. Brasil. Ministério da Saúde. DATASUS. Sistema de Informação de Mortalidade-SIM [Internet] Brasília; 2017 [citado 2017 out. 15]. Disponível em: http://www2.datasus.gov.br/DATASUS/index.php?area=060701

5. Brasil. Ministério da Saúde; Secretaria da Atenção à Saúde, Departamento de Atenção Básica. Atenção ao pré-natal de baixo risco [Internet] Brasília; 2012 [citado 2017 out. 20]. Disponível em: http://bvsms.saude.gov.br/bvs/publicacoes/cadernos_atencao_basica_32_prenatal.pdf

6. Brasil. Ministério da Saúde; Secretaria de Atenção à Saúde, Departamento de Ações Programáticas Estratégicas. Gestação de alto risco: manual técnico[internet] Brasília; 2012 [acesso em 2017 set. 20]. Disponível em: http://bvsms.saude.gov.br/bvs/publicacoes/manual_ tecnico_gestacao_alto_risco.pdf

7. Organização Mundial da Saúde. Avaliação da qualidade do cuidado nas complicações graves da gestação: a abordagem do near miss da OMS para a saúde materna. Ginebra: OMS; 2014.

8. Franco TB, Merhy EE. Cartografias do trabalho e cuidado em saúde. Tempus Actas Saúde Coletiva. 2012;6(2):163-52.

9. Bareta PA. Fórmula para o cálculo do tamanho mínimo da amostra: estatística aplicada às ciências sociais. Florianópolis: Ed.UFSC; 2012.

10. Merhy EE. Saúde: cartografia do trabalho vivo. São Paulo: Hucitec; 2002.

11. Queiroz MVO, Brasil E M, Alcantrara CM, Carneiro MGO. Perfil da gravidez na adolescência e ocorrências clínico-obstétricas. Rev Rene. 2014;15(3):455-62. DOI: 10.15253/2175-6783.2014000300010.

12. Dias ACG, Patias ND, Fiorin PC, Dellatore MZ. O significado da maternidade na adolescência para jovens gestantes. Rev Bras Hist Ciênc Soc. 2011;3(6):167-53.

13. Rodriguez FT, Carneiro TF. Maternidade tardia e ambivalência: algumas reflexões. Tempo Psicanalítico. 2013;45(1):111-21.

14. Oliveira DR, Cruz MKP. Estudo das indicações de parto cesáreo em primigestas no município de Barbalha-Ceará. Rev Rene. 2010;11(3):11421. DOI: http://dx.doi.org/10.15253/rev\%20rene.v11i3.4601

15. Moraes PGS, Holanda VR, Pinheiro HDM. Perfil epidemiológico de primíparas atendidas em uma maternidade de alto risco. Enferm Obstétr. 2014;1(2):45-50.

16. Brasil. Ministério da Saúde. Saúde Brasil 2013: uma análise da situação de saúde e das doenças transmissíveis relacionadas à pobreza [internet] Brasília; 2014 [citado 2017 set. 15]. Disponível em: http://bvsms.saude.gov.br/bvs/publicacoes/saude_brasil_2013_analise_ situacao_saude.pdf

17. Bashour H, Haddad GS, Dejong J, Ramadan MC, Hassan S, Breebaart M, et al. A cross sectional study of maternal 'near-miss' cases in major public hospitals in Egypt, Lebanon, Palestine and Syria. BMC Pregnancy Childbirth. 2015 15:296. DOI: https://doi.org/10.1186/ s12884-015-0733-7.

18. Nobrega MF, Santos MTBR, Davim RMB, Oliveira LFM, Alves ESRC, Rodrigues ESRC. Fatores associados à via de parto em mulheres com pré-eclâmpsia. Rev Bras Ginecol Obstet. 2014;36(6):259-63. DOI: http://dx.doi.org/10.1590/S0100-720320140004812.

19. Rulisa S, Umuziranenge I, Small M, Roosmalen JV. Maternal near miss and mortality in a tertiary care hospital in Rwanda. BMC Pregnancy Childbirth, 2015;15-203. DOI: https://doi.org/10.1186/s12884-015-0619-8

20. Seignemartin BA, Jesus LR, Vergilio MSTG, Silva M. Avaliação da qualidade das anotações de enfermagem no pronto atendimento de um hospital escola. Rev Rene. 2013;14(6):1123-32. DOI: http://dx.doi.org/10.15253/rev\%20rene.v14i6.3724

21. Campana S G, Chavez J H, Haas P. Diagnóstico laboratorial do líquido amniótico. J Bras Patol Med Laborat. 2003;39(3):215-8.

22. Brasil. Ministério da Saúde; Comissão Nacional de Informações Tecnológicas no SUS Diretriz Nacional de Assistência ao Parto Normal [internet] Brasília: CONITEC; 2016 [citado 2017 nov. 15]. Disponível em: http://conitec.gov.br/images/Consultas/2016/Relatorio_DiretrizPartoNormal_CP.pdf 
23. Organização Mundial da Saúde. Maternidade segura: assistência ao parto normal: um guia prático [Internet] Brasília: MS; 1996 [citado 2017 nov. 15]. Disponível em: http://pesquisa.bvsalud.org/bvsms/resource/pt/mis-9570

24. Organização Mundial da Saúde, Departamento de Saúde Reprodutiva e Pesquisa. Declaração da OMS sobre Taxas de Cesáreas [Internet] Genebra; 2014 [citado 2017 nov. 20]. Disponível em: http://apps.who.int/iris/bitstream/handle/10665/161442/who_rhr_15.02_por.pdf;js essionid=4E023CBB9F015EF451CAA90663B9113C? sequence $=3$

25. Brasil. Ministério da Saúde. Humanização do Parto: humanização do parto e do nascimento [Internet]. Brasília: 2014 [citado 2017 nov. 22]. Disponível em: http://bvsms.saude.gov.br/bvs/publicacoes/parto.pdf

26. Barbieri M, Henrique AJ, Chors FM, Maia NL, Gabrielloni MC. Banho quente de aspersão, exercícios perineais com bola suíça e dor no trabalho de parto. Acta Paul Enferm. 2013; 26(5):478-84. DOI: http://dx.doi.org/10.1590/S0103-21002013000500012

27. Wei CY, Gualda DMR, Junior APOS. Movimentação e dieta durante o trabalho de parto: a percepção de um grupo de puérperas. Texto Contexto Enferm. 2011; 20(4): 717-25. DOI: http://dx.doi.org/10.1590/S0104-07072011000400010.

28. Brasil. Ministério da Saúde. Portaria n. 1.459, de 24 de junho de 2011. Institui no âmbito do Sistema Único de Saúde - SUS - a Rede Cegonha [internet] Brasília; 2011 [citado 2017 set. 12]. Disponível em: http://bvsms.saude.gov.br/bvs/saudelegis/gm/2011/prt1459_24_06_2011. html

29. Gomes AMA, Caprara A, Landim LOP, Vasconcelo IMCF. Relação médico-paciente: entre o desejável e o possível na Atenção Primária à Saúde. Physis Rev Saúde Coletiva. 2012;22 (3): 1101-19. DOI: http://dx.doi.org/10.1590/S0103-73312012000300014

30. Fogaça NR. Ferrari RAP, Gabani FL, Soares NT, Tacla MTGM, Oliveira GS. Operacionalização de grupos de pré-natal: percepção dos profissionais do serviço da atenção primária à saúde. Rev Pesq Qualit. 2017;5(7):128-42. 